\title{
APLIKASI PENCARIAN TEMPAT WISATA MENGGUNAKAN METODE LOCATION BASED SERVICE PADA WILAYAH KABUPATEN TIMOR TENGAH SELATAN BERBASIS ANDROID
}

\author{
Nopriyanus V Y R Bani, Ahmad Faisol Faisol, F. X Ariwibisono \\ Program Studi Teknik Informatika S1, Fakultas Teknologi Industri \\ Institut Teknologi Nasional Malang, Jalan Raya Karanglo km 2 Malang, Indonesia \\ Anto.bani13@gmail.com
}

\begin{abstract}
ABSTRAK
Dalam pengembangan wisataan di kabupaten TTS masih sangat minim, pengembangan pariwisata yang dilakukan oleh pihak pengelola masih terlihat belum optimal dibandingkan dengan pengembangan wisataan di daerah lainnya, selama ini jika ingin mengunjungi tempat pariwisata yang belum kita tahu tempatnya, pasti kita akan bertanya pada orang lain atau pun browsing di internet untuk mengetahui tempat tujuan kita. ini memang membantu, namun terkadang informasi yang kita dapat bisa saja keliru, atau bisa saja kita tersesat karna memilih jalan yang salah menuju ke tempata tujuan pariwisata yang akan di tujuh. Oleh karena itu, hal ini akan sangat menghambat ataupun menyusahkan dan membuang waktu dalam perjalnan menuju tempat pariwisata yang telah di pilih pada kab TTS.

Dalam Pembuatan aplikasi ini, menggunakan Android Studio versi 3.4.1 dan menggunakan metode location based service yang digunakan untuk fungsi navigasi ke Lokasi wisata pada kabupaten Timor Tengah Selatan yang ditampilkan dalam peta berupa penanda titik lokasi. sehingga data koordinat fasilitas dari setiapa wisata yang ada sudah dimasukan informasi lengkap.

Berdasarkan hasil dari perancangan dan implementasi dari aplikasi pencarian tempat wisata menggunakan metode locaation based service pada kabupaten Timor Tengah Selatan berbasis android maka dari pengujian fungsional yang dilakukan pada 3 sistem operasi yang berbeda yaitu Nouget, pie, oreo didapat kesimpulan fungsi location based service berjalan dengan baik.
\end{abstract}

\section{Kata kunci : Timor Tengah Selatan, Wisata, Location Based service, Android, Google Maps}

\section{PENDAHULUAN}

\subsection{Latar Belakang}

Kekayaan potensi pariwisata pada Provinsi Nusa Tenggara Timur, yakni Kabupaten Timor Tengah Selatan juga memiliki potensi dan daya tarik yang sangat unik dan menarik. Kabupaten Timor Tengah Selatan sendiri yang disingkat TTS berada pada ketinggian 800 -1000 meter diatas permukaan laut dan memiliki udara yang sejuk, memiliki beranekaragam potensi dan daya tarik wisata berupa pegunungan, alam pantai dan adanya potensi daya tarik wisata budaya lokal.

Pengembangan kepariwisataan di kabupaten TTS masih sangat minim, pengembangan pariwisata yang dilakukan oleh pihak pengelola terlihat masih sangat kuarang optimal dibandingkan pengembangan pada kepariwisataan di kabupaten lainnya pada provinsi NTT, selama ini jika ingin mengunjungi tempat pariwisata yang belum kita tahu tempatnya, pasti kita akan bertanya pada orang lain atau pun browsing di internet untuk mengetahui tempat tujuan kita. ini memang membantu, namun terkadang informasi yang kita dapat bisa saja keliru, atau bisa saja kita tersesat karna memilih jalan yang salah menuju ke tempata tujuan pariwisata yang akan di tujuh. Oleh karena itu, hal ini akan sangat menghambat ataupun menyusahkan dan membuang waktu dalam perjalnan menuju tempat pariwisata yang telah di pilih pada kab TTS.

Oleh karena itu, dibuat lah aplikasi mobile dengan menggunakan konsep/metode Location Based Service (LBS) di platform android. LBS atau layanan berbasis lokasi, sesuai namanya merupakan suatu layanan yang memberikan informasi rancangan geografis terhadap lokasi sebuah perangkat bergerak. Dengan aplikasi ini, fasilitas pariwisata dan rute akan ditampilkan. Baik itu informasi peta maupun rute perjalanan menuju ke lokasi pariwisata di kabupaten TTS. Dengan aplikasi mobile dengan layanan berbasis lokasi ini, diharapkan dapat mempermudah dalam mencari tempat pariwisata yang berada di kabupaten TTS untuk dapat menunjang dan juga meningkatkan layanan yang disediakan pemerintah kab TTS.

\subsection{Rumusan Masalah}

Berdasarkan latar belakang masalah diatas, dapat dirumuskan permasalahan yang akan dibahas adalah :

1. Bagaimana membuat suatu sistem yang dapat mencari tempat pariwisata terdekat dengan posisi pengguna smartphone android?

2. Bagaimana menerapkan metode Location Based Service (LBS) untuk melakukan pencarian 
lokasi tempat pariwisata di kabupaten TTS berbasis Android?

\subsection{Tujuan Penilitian}

Adapun yang menjadi tujuan skripsi ini adalah sebagai berikut :

1. Merancang suatu sistem untuk melakukan pencarian tempat pariwisata yang ada di kabupaten TTS.

2. Menerapkan metode location based service pada aplikasi android pencarian tempat pariwisata di kabupaten TTS.

\subsection{Batasan Masalah}

Dalam penyusunan skripsi agar menjadi sistematis yang mudah di mengerti, maka akan diterapkan beberapa batasan masalah. Adapun batasan masalah ini meliputi :

1. Pada penelitian ini hanya mengembangkan algoritma pemrograman sesuai dengan metode Location Based Service (LBS) pada perangkat berbasis android.

2. Data yang diambil pada penelitian ini yaitu data tentang pariwisata alam, pariwisata religi, pariwisata kuliner dan data titik koordinat dari lokasi tempat pariwisata tersebut.

3. Bahasa pemrograman yang digunakan untuk mengembangkan sistem adalah bahasa pemrograman Java, Xml, dan Database Mysql.

4. Pembuatan aplikasi menggunakan Android Studio.

5. Untuk menjalankan sistem ini harus terkoneksi ke internet.

\section{TINJAUAN PUSTAKA}

\subsection{Penilitian Terkait}

Luasnya kampus Universitas Mulawarman membuat banyak orang baru yang dating pada kampus tersebut kesulitan dalam mencari tempat yang berada di lingkungan kampus. Dari masalah tersebut maka dibuatkanlah aplikasi android dengan nama Unmaps yang memanfaatkan metode Location Based Service (LBS) untuk menentukan suatu lokasi di Universitas Mulawarmantersebut. Pada pengujian aplikasi ini aplikasi terdapat fitur posisi pengguna dan lokasi bangunan yang ada di Universitas Mulawarman, profil kampus,fakultas dan jurusan. Sehingga informasi yang ditampilkan dapat memenuhi kebutuhan pengguna aplikasi UnMaps ini. (Budiman Edy 2016)

Seorang user tidak tahu posisi dimana dia berada atau tersesat. Oleh karena itu dibuatkan sistem pelacakan lokasi Location Based Service (LBS) untuk mendapatkan informasi lokasi melalui jaringan dan juga menggunakan metode Advanced Positioning untuk meningkatkan akurasi lokasi menggunakan GPS tersebut. Dari hasil pengimplementasian sistem didapatkan informasi lokasi seputar lokasi user sehingga penggunaan aplikasi ini harus tetap terhubung ke internet. Ketika kita memilih "Rute" di menu, maka aplikasi akan menunjukkan lokasi pengguna berada. (Anwar Badrul et al 2014)

\subsection{Landasan Teori}

\subsubsection{Kabupaten TTS}

Kabupaten Timor Tengah Selatan, yang dimana ibu kotanya SoE adalah salah satu kabupaten yang berada pada Provinsi Nusa Tengarah Timur, pada utara kabupaten Timor Tengah Selatan berbatasan langsung dengan kabupaten Timor Tengah Utara atau yang disingkat TTU, sebelah timur Kabupaten Timor Tengah Utara berbatasan langsung dengan Kabupaten Belu, sebelah barat kab TTS berbatasan dengan Kabupaten Kupang dan di bagian selatan terdapat Laut Timor, luas wilayah Kabupaten Timor Tengah Selatan yaitu 3.995.88 kilometer persegi, Kabupaten TTS berupa daratan. Wilayah administrasi Kabupaten Timor Tengah Selatan terdiri dari 32 Kecamatan yang terdiri atas 228 Desa dan 12 Kelurahan [3].

\subsubsection{Location Based Service}

Location Based Service (LBS) atau layanan berbasis lokasi adalah istilah umum yang digunakan untuk menggambarkan teknologi yang digunakan untuk menemukan lokasi perangkat yang digunakan. Menurut Qusay H. Mahmoud, LBS dapat digunakan untuk mengetahui posisi dari pengguna, dua unsur utama LBS adalah :

1. Location Manager (Api Maps)

Menyediakan tools/source untuk LBS, Application Programming Interface (API) Maps menyediakan fasilitas untuk menampilkan, memanipulasi peta beserta fitur-fitur lainya seperti tampilan satelit, jalan, maupun gabungannya.

2. Location Providers (Api Location)

Pengguna dapat menetukan lokasinya, melacak gerakan/perpindahan, serta kedekatan dengan lokasi tertentu dengan mendetaksi perpindahan.

LBS dapat dibagi menjadi dua, yaitu :

1. Pull Service: Layanan hanya diberikan ketika ada permintaan dari pengguna.

2. Push Service: Layanan diberikan langsung oleh service provider tanpa menuggu permintaan daari pengguna.

Yang dibangun dari teknologi informasi dan komunikasi baru (New Information and Communication Technologies / NICTS) yang didalamnya meliputi: system telekomunikasi mobile dan perangkat genggam, dengan data berasal dari internet dan Sistem Informasi Geografis (SIG) yang menggunakan spatial database. 


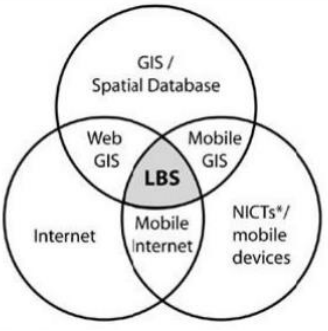

Gambar 2.1 Perpotongan Teknologi LBS

Dalam Layanan Berbasis Lokasi terdapat lima komponen yaitu meliputi:

1. Mobile Devices: Suatu alat yang digunakan oleh pengguna untuk meminta informasi yang dibutuhkan. Informasi dapat di minta dalam bentuk suara, gambar, dan teks.

2. Comunication Network: Komponen kedua adalah jaringan komunikasi yang mengirim data pengguna dan informasi yang diminta dari mobile terminal ke Sevice Provider kemudian mengerimkan kembali informasi yang diminta ke pengguna. Communication Network dapat berupa jaringa seluler (GSM, CDMA), Wireless Local Area Network (WLAN), atau Wireless Wide Area Network (WWAN).

3. Positioning Component: Untuk memproses suatu layanan maka posisi pengguna harus diketahui.

4. Service and Aplication Provider: Penyedia layanan menawarkan berbagai macam layanan kepada pengguna dan bertanggung jawab untuk memproses informasi yang diminta oleh pengguna.

5. Data and Content Provider: Penyedia layanan tidak selalu menyimpan semua data yang dibutuhkan yang bisa diakses oleh pengguna. Untuk itu, data dapat diminta dari data dan content provider.

Dalam mengimplementasi LBS, ada 2 pendekatan dasar yang digunakan, yaitu:

1. Memproses data di lokasi dan mengirimkan hasil ke alat.

2. Mendapatkan data lokasi dari alat tersebut berdasarkan aplikasi yang menggunakannya secara langsung.

Sedangkan aplikasi bisa menggunakan beberapa pendekatan yang disediakan, yaitu:

1. Menggunakan jaringan telpon seluler, akurasi dari metode ini tergantung kepada ukuran dari sel. Kelemahannya adalah sering tidak akurat karena keakuratannya tergantung kualitas jaringan dan coverage BTS.

2. Menggunakan Satelit, lebih akurat dari jaringan telepon, karena menggunakan bantuan satelit GPS untuk mendapatkan posisi data yang akurat.[4]

\subsubsection{Java}

Java adalah suatu teknologi pada dunia software komputer, yang merupakan bahasa pemrograman, dan juga suatu platform. Sebagai bahasa pemrograman, Java dikenal sebagai bahasa pemrograman tingkat tinggi. Java mudah dipelajari, terutama bagi programmer yang telah mengenal $\mathrm{C} / \mathrm{C}++$. Java merupakan bahasa pemrograman berorientasi objek paradigma pemrograman masa depan. Sebagai bahasa pemrograman Java dirancang menjadi handal dan aman.

Java bersifat neutral architecture, karena Java Compiler yang digunakan untuk mengkompilasi kode program Java dirancang untuk menghasilkan kode yang netral terhadap semua arsitektur perangkat keras yang disebut sebagai Java Bytecode[5].

\subsubsection{MySQL}

MySQL merupakan software RDBMS (atau server database) yang dapat mengelola database dengan sangat cepat, dapat menampung data dalam jumlah sangat besar, dapat diakses oleh banyak user (multi-user), dan dapat melakukan suatu proses secarasinkron atau berbarengan (multi-threaded).

Contoh aplikasi yang menggunakan MySQL yaitu berupa: Joomla www.jommla.org Wordpress www.wordpress.com MyBB www.mybb.com phpBB www.phpbb.com dan masih banyak yang lainnya[6].

\subsubsection{Android Studio}

Android studio adalah IDE (Integrated Development Environment) resmi untuk pengembangan aplikasi Android dan bersifa topen source atau gratis. Peluncuran Android Studio ini di umumkan oleh Google pada 16 mei 2013 pada event Google I/O Conference untuk tahun 2013. Sejak saat itu, Android Studio mengantikan Eclipse sebagai IDE resmi untuk mengembangkan aplikasi Android, Android studio sendiri dikembangkan berdasarkan IntelliJ IDEA yang mirip dengan Eclipse disertai dengan ADT plugin (Android Development Tools). Android studio memilikifitur :

1. Projek berbasispada Gradle Build

2. Refactory dan pembenahan bug yang cepat

3. Tools baru yang bernama "Lint" diklaim dapat memonitor kecepatan, kegunaan, serta kompetibelitas aplikasi dengan cepat.

4. Mendukung Proguard And App-signing untuk keamanan.

5. Memiliki GUI aplikasi android lebih mudah.

6. Didukung oleh Google Cloud Platfrom untuk setiap aplikasi yang dikembangkan [7].

\subsubsection{Java Script Object Nonation (JSON)}

JSON (JavaScript Object Notation) adalah format pertukaran data yang ringan, mudah dibaca dan ditulis oleh manusia, serta mudah diterjemahkan dan dibuat (generate) oleh komputer. Format ini dibuat berdasarkan bagian dari Bahasa Pemprograman JavaScript, Standar ECMA-262 Edisi ke-3 - Desember 1999. JSON merupakan format teks yang tidak bergantung pada bahasa pemprograman apapun karena menggunakan bahasa yang sangat 
umum digunakan oleh programmer seperti C termasuk C, C++, C\#, Java, JavaScript, Perl, Python dll. Oleh karena sifat-sifat tersebut, menjadikan JSON ideal sebagai bahasa pertukaran-data. [8].

\subsubsection{Google Maps API}

Google Maps API yaitu merupakan sebuah layanan (service) yang dibuat oleh Google ke para pengguna untuk memanfaatkan Google Map dalam mengembangkan aplikasi tersebut Google Maps API menyediakan fitur-fitur untuk manipulsi peta, dan menambahkan konten melalui berbagai jenis services yang ada, serta mengijinkan kepada pengguna untuk membangun aplikasi enterprise di dalam websitenya. Pengguna juga dapat memanfaatkan layanan-layanan yang ditawarkan oleh Google Maps, Google juga menyediakan layanan ini secara gratis atau Cumacuma kepada pengguna di seluruh dunia [9].

\section{METODE PENELITIAN}

\subsection{Sistem yang akan dikembangkan}

Aplikasi yang akan dikembangkan ini merupakan sistem pencarian tempat pariwisata di kabupaten Timor Tengah Selatan menggunakan perangkat android. Dimana cara kerjanya menggunakan Location Based Service dengan melakukan fungsi navigasi untuk menemukan lokasi pariwisata yang dipilih dan menampilkan informasi dari wisata yang dipilih.

\subsection{Perancangan Sistem}

Sistem yang akan dibangun pada penelitian ini yaitu implementasi Location Based Services pada perangkat android dimana pengguna dapat mencari dan menemukan lokasi pariwisata yang ada di dalam aplikasi yang akan dikembangkan. Oleh karena itu aplikasi harus memenuhi kriteria :

1. Aplikasi harus mampu menampilkan lokasi pengguna dan lokasi tempat pariwisata

2. Aplikasi harus mampu menampilkan daftar tempat Pariwisata yang ada di kabupaten Timor Tengah Selatan

3. Aplikasi harus mampu menjalankan fungsi navigasi dan mengarahkan ke fasilitas tempat pariwasata yang dituju

4. Aplikasi dapat memberikan informasi mengenai tempat Pariwisata yang dipilih

\subsection{Desain Sistem}

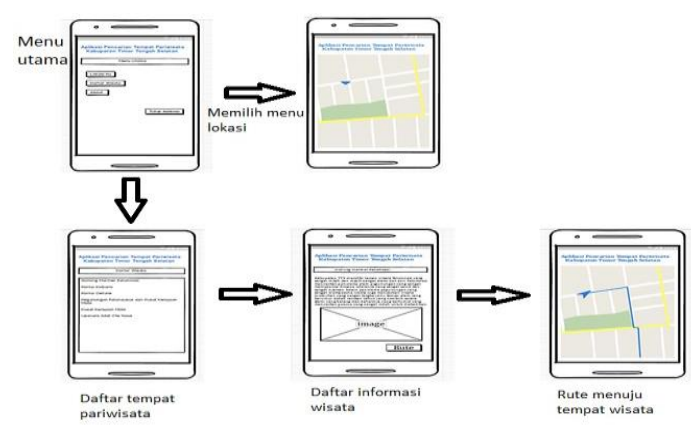

Gambar 3.1 Tampilan Rancangan Desain Sistem

Pertama, aplikasi akan menentukan lokasi pengguna untuk melakukan pencarian lokasi tempat pariwisata. Pada gambar 3.1 ditampilkan diagram blok yang menjelaskan bahwa untuk melakukan pencarian rute dapat dilakukan dengan memilih menu Daftar tempat pariwisata. Kemudian memilih salah satu datar tempat pariwisata yang ditampilkan, lalu klik Rute, maka akan ditampilkan rute/jalur menuju lokasi tempat pariwisata tersebut dan pengguna tinggal mengikuti jalur/rute yang telah ditampilkan.

\subsection{Struktur Menu}

Dari aplikasi yang akan dikembangkan, terdapat beberapa menu yang ditampilkan untuk menunjang kebutuhan pengguna. Dibawah ini merupakan gambar struktur menu

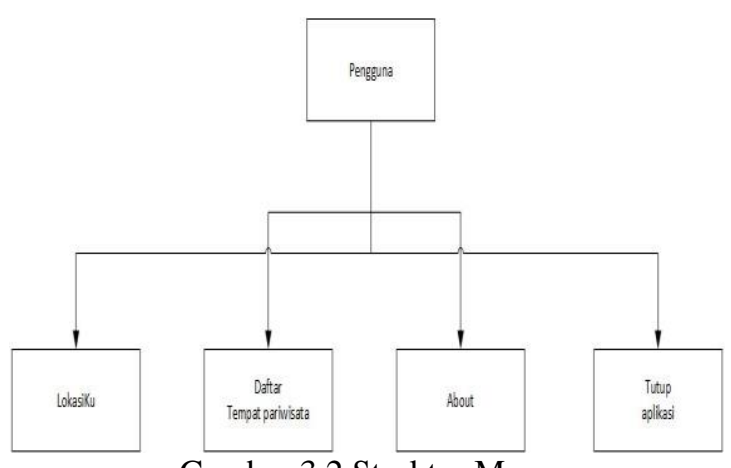

Gambar 3.2 Struktur Menu

Seperti pada gambar 3.2 Pada aplikasi pencarian lokasi tempat wisata di kabupaten TTS tersedia 4 Menu, yaitu :

1. Menu Lokasiku untuk melihat lokasi dimana kita berada.

2. Menu Daftar tempat wisata menyediakan daftar informasi tempat wisata di kabupaten Timor Tengah Selatan

3. Menu About untuk menampilkan informasi tentang aplikasi pencarian lokasi tempat pariwisata ini

4. Dan menu Tutup Aplikasi untuk menghentikan/menutup aplikasi. 


\subsection{Flowchart}

Untuk cara kerja dari aplikasi yang akan dikembangkan tentang aplikasi pencarian lokasi tempat Pariwisata di kabupaten Timor Tengah Selatan, dapat dilihat seperti pada gambar 3.3 dibawah ini

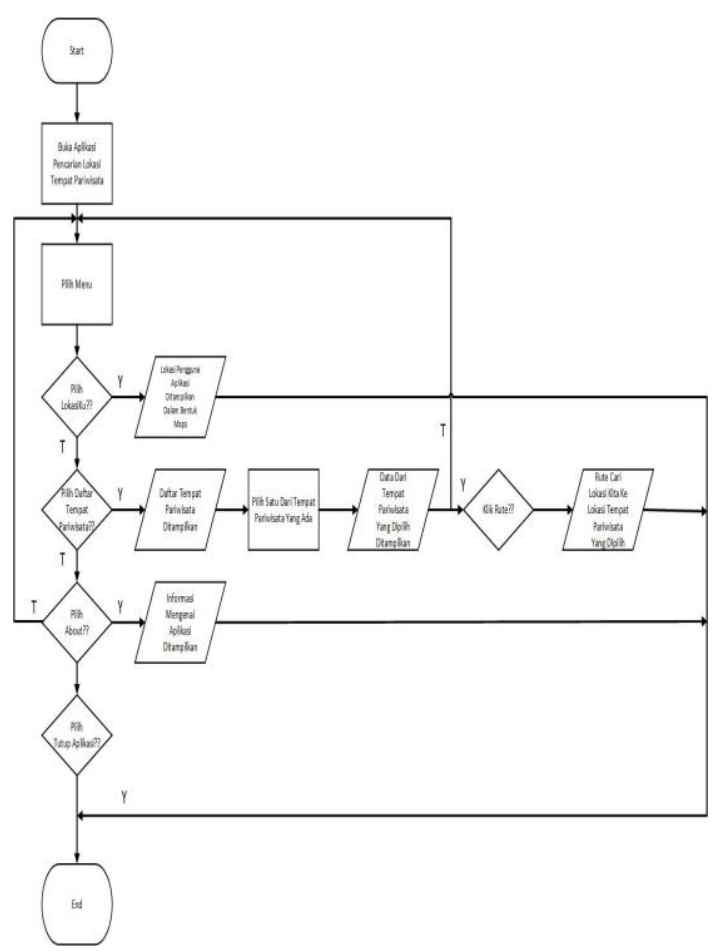

Gambar 3.3 Tampilan flowchart aplikasi

Pada gambar 3.3 ditampilkan flowchart dari sistem/aplikasi yang akan dikembangkan. Dimana aplikasi dimulai dari start lalu membuka aplikasi pencarian lokasi tempat wisata dan akan ditampilkan menu utama. Menu utama ada 4, yaitu :

1. Jika pengguna memilih menu Lokasiku, maka akan menampilkan lokasi pengguna aplikasi saat ini

2. Jika memilih menu Daftar wisata, maka sistem akan menampilkan daftar tempat wisata yang ada di kabupaten Timor Tengah Selatan, kemudian kita memilih salah satu dari wisata yang ada. Setelah memilih maka akan ditampilkan data/informasi mengenai wisata tersebut. Jika kita memilih untuk melihat rute/petunjuk jalan ke lokasi tersebut, klik tombol "rute" maka sistem akan menampilkan lokasi pengguna sekaligus rute menuju lokasi tempat wisata tersebut

3. Jika memilih menu About, maka akan ditampilkan informasi mengenai aplikasi pencarian lokasi temapat wisata di kabupaten Timor Tengah Selatan

4. Jika memilih menu Tutup Aplikasi maka aplikasi akan dihentikan.

\section{HASIL DAN PEMBAHASAN}

4.1 Implementasi Sistem

Implementasi sistem adalah proses menerapkan rancangan sistem yang telah dibuat agar bisa dijalankan pada kenyataannya. Implemetasi sistem ini dapat mengetahui sejauh mana keberhasilan dari rancangan yang telah dibuat. Untuk menunjang implementasi sistem informasi geografis kecamatan woja kabupaten dompu berbasis website harus didukung dengan perangkat keras dan lunak.

\subsubsection{Tampilan Menu Utama}

Halaman utama adalah halaman yang pertama muncul pada saat program dijalankan. Isi dari menu ini seperti yang ditunjukkan pada Gambar 4.1 sebagai berikut.

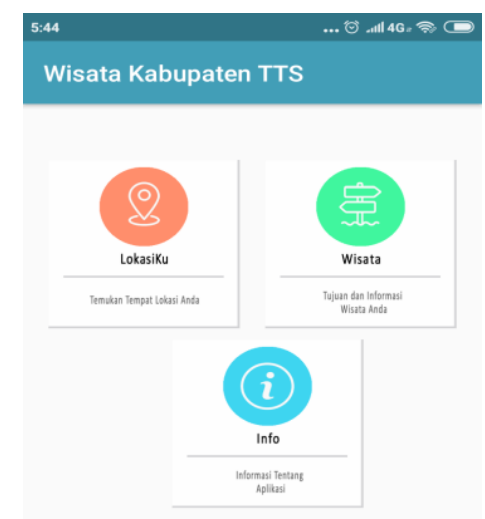

Gambar 4.1 Tampilan Menu Utama

\subsubsection{Tampilan Menu LokasiKu}

Halaman Lokasiku berfungsi untuk melihat lokasi posisi pengguna berada dan juga terdapat lokasi-lokasi pariwisata yang berada di Kabupaten Timor Tengah Selatan, seperti pada gambar 4.2.

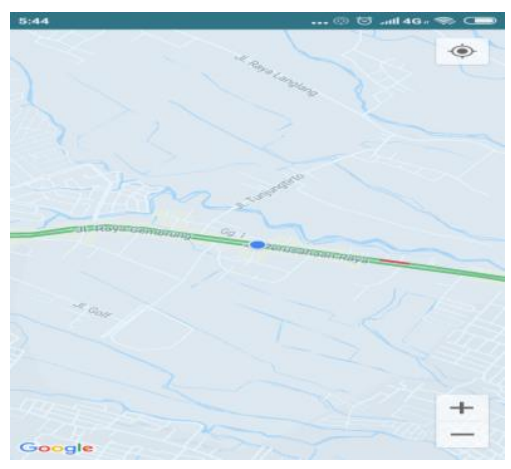

Gambar 4.2 Tampilan Menu Lokasi

\subsubsection{Tampilan Menu Wisata}

Halaman menu wisata berfungsi untuk mencari wisata yang akan dituju seperti, Wisata Alam, Wisata Religi, Wisata Kuliner, yang di tampilkan pada gambar 4.3. 


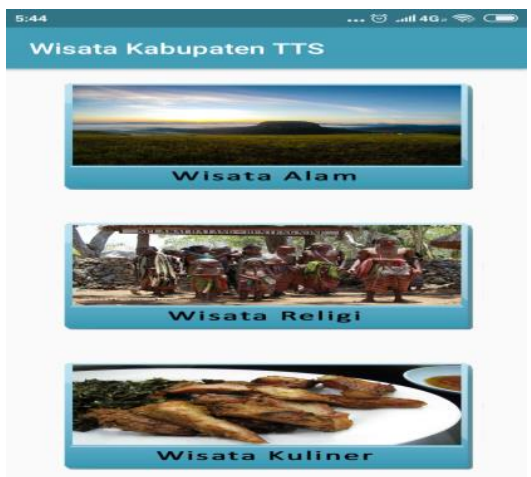

Gambar 4.3 Tampilan Menu Wisata

\subsubsection{Tampilan Menu Wisata Alam}

Halaman menu wisata alam berfungsi untuk menampilakan daftar wisata alam yang berada di Kabupaten Timor Tengah Selatan, yang dit ampilkan pada gambar 4.4

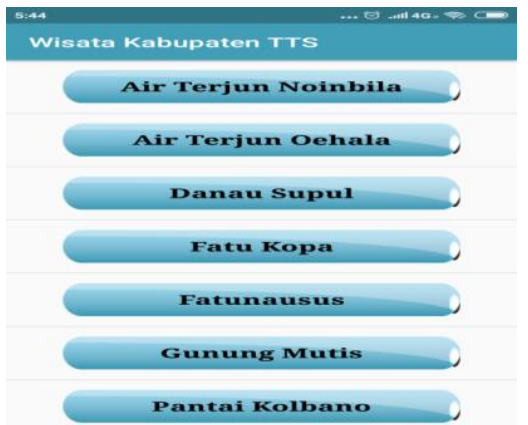

Gambar 4.4 Tampilan Menu Wisata Alam

\subsubsection{Tampilan Informasi Wisata Alam}

Ketika pengguna memilih salah satu Wisata Alam, akan muncul informasi dari wisata alam seperti yang ditujukan pada gambar 4.5. Setelah informasi ditampilkan, pengguna cukup klik pada tombol Map untuk menampilkan titik koordinat lokasi yang dipilih.

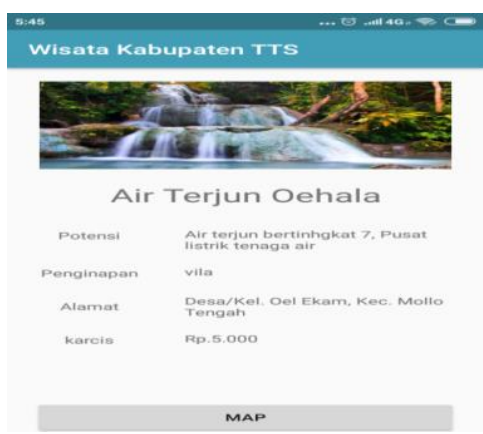

Gambar 4.5 Tampilan Informasi Wisata Alam

\subsubsection{Tampilan Lokasi Wisata Alam}

Setelah klik tombol map akan tampil titik koordinat wisata alam yang akan di tuju seperti pada gambar 4.6. kemudian klik tombol panah untuk menuju lokasi wisata alam tersebut.

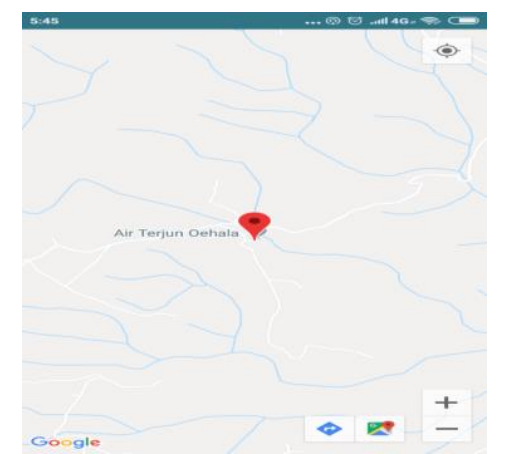

Gambar 4.6 Tampilan Lokasi Wisata Alam

\subsubsection{Tampilan Rute Perjalanan}

Tampilan memulai perjalanan menuju lokasi wisata alam. Untuk lebih jelasnya dapat dilihat pada Gambar 4.7.

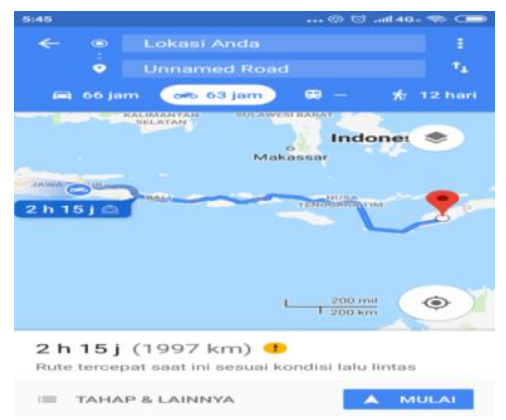

Gambar4.7 Tampilan Rute Perjalanan Wisata Alam

\subsubsection{Tampilan Menu Wisata Religi}

Halaman menu wisata religi berfungsi untuk menampilakan daftar wisata religi yang berada di Kabupaten Timor Tengah Selatan, yang ditampilkan pada gambar 4.8

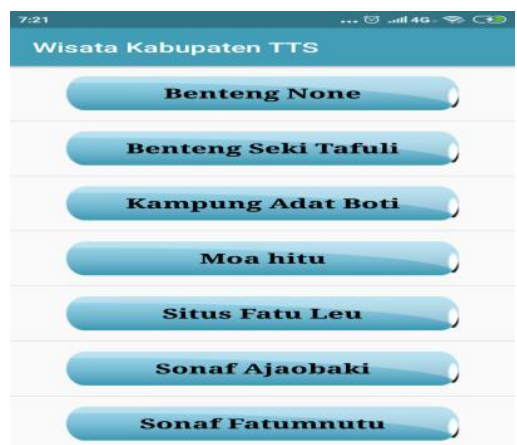

Gambar 4.8 Tampilan Menu Wisata Religi

\subsubsection{Tampilan Informasi Wisata Religi}

Ketika pengguna memilih salah satu wisata religi, akan muncul informasi dari wisata religi seperti yang ditujukan pada gambar 4.9. Setelah 
informasi ditampilkan, pengguna cukup klik pada tombol Map untuk menampilkan titik koordinat lokasi yang dipilih.

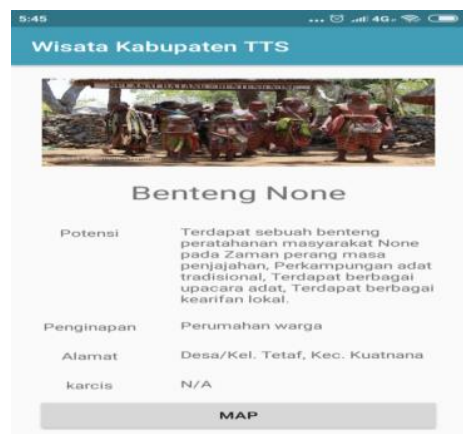

Gambar 4.9 Tampilan Informasi Wisata Religi

\subsubsection{Tampilan Lokasi Wisata Religi}

Setelah klik tombol map akan menampilkan lokasi wisata religi yang akan di tuju seperti pada gambar 4.10. kemudian klik tombol panah untuk menuju lokasi wisata religi tersebut.

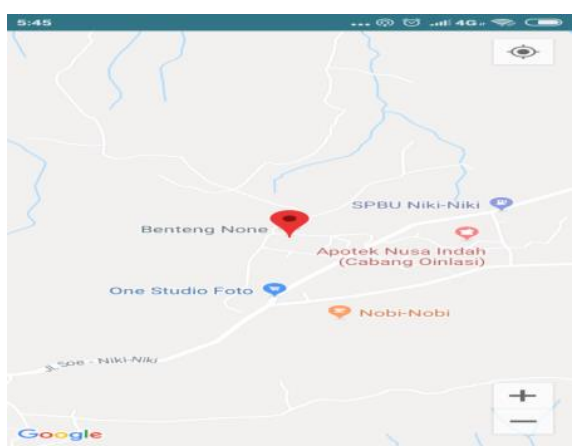

Gambar 4.10 Tampilan Lokasi wisata Religi

\subsubsection{Tampilan Rute Perjalanan}

Tampilan rute perjalanan menuju lokasi wisata religi. Untuk lebih jelasnya dapat dilihat pada Gambar 4.11.

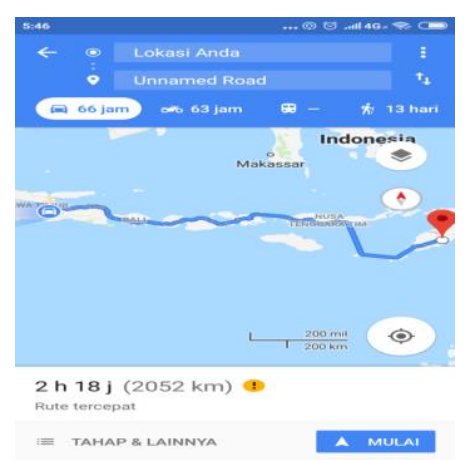

Gambar4.11 Tampilan Rute Perjalanan Wisata Religi

\subsubsection{Tampilan Menu Wisata Kuliner}

Halaman menu wisata kuliner berfungsi untuk menampilakan daftar wisata kuliner yang berada di Kabupaten Timor Tengah Selatan, yang ditampilkan pada gambar 4.12

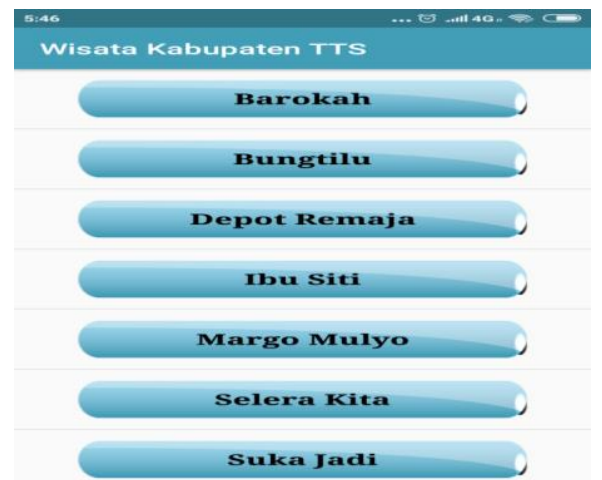

Gambar 4.12 Tampilan Menu Wisata Kuliner

\subsubsection{Tampilan Informasi Wisata Kuliner}

Ketika pengguna memilih salah satu wisata kuliner, akan muncul informasi dari wisata kuliner seperti yang ditujukan pada gambar 4.13. Setelah informasi ditampilkan, pengguna cukup klik pada tombol Map untuk menampilkan titik koordinat lokasi yang dipilih. 


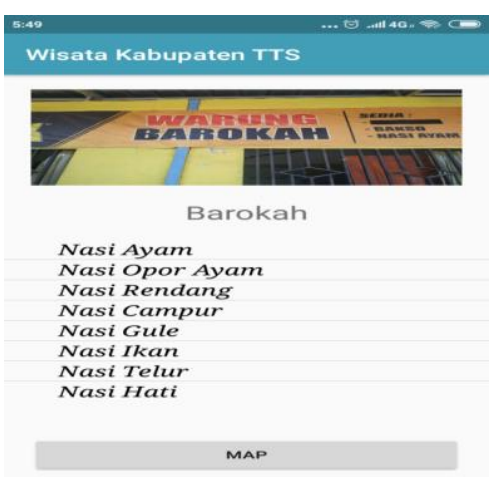

Gambar 4.13 Tampilan Informasi Wisata Kuliner

\subsubsection{Tampilan Lokasi Wisata Kuliner}

Setelah klik tombol map akan menampilkan lokasi wisata Kuliner yang akan di tuju seperti pada gambar 4.14. kemudian klik tombol panah untuk menuju lokasi wisata kuliner tersebut.

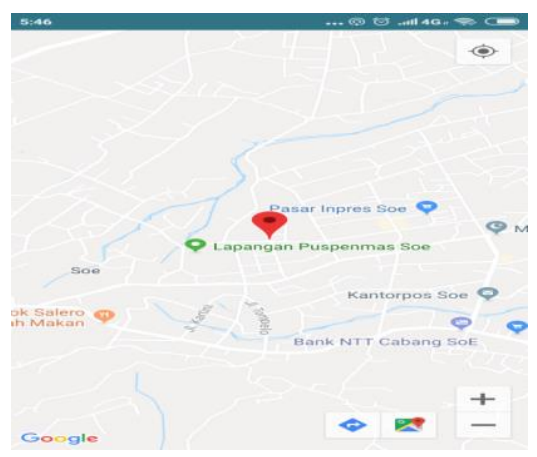

Gambar 4.14 Tampilan Lokasi wisata Kuliner

\subsubsection{Tampilan Rute Perjalanan}

Tampilan rute perjalanan menuju lokasi wisata Kuliner. Untuk lebih jelasnya dapat dilihat pada Gambar 4.15.

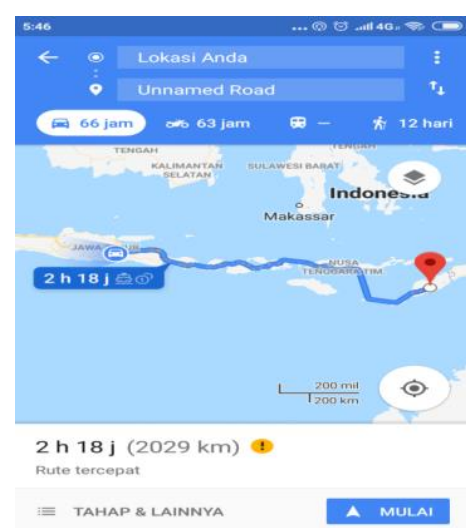

Gambar4.11 Tampilan Rute Wisata Kuliner

\subsubsection{Menu Info}

Pada menu about berisikan informasi secara garis besar dari aplikasi, yang ditampilkan seperti pada gambar 4.15 .

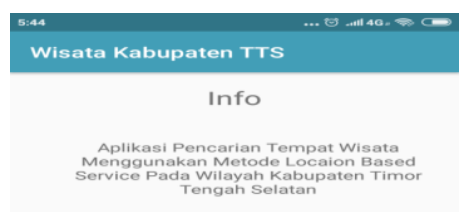

Gambar 4.15 Menu Info

\subsection{Pengujian Sistem}

\subsubsection{Pengujian Fungsional}

Pengujian sistem merupakan proses menampilkan sistem dengan maksud untuk menemukan adanya kesalahan atau tidak pada sistem sebelum sistem dipublikasikan untuk digunakan oleh masyarakat. Hasil pengujian sistem ditunjuakkan pada Tabel 4.1 sebagai berikut.

Tabel 4.1 Hasil Pengujian fungsional

\begin{tabular}{|c|l|c|c|c|c|c|}
\hline \multirow{2}{*}{ No } & \multicolumn{2}{|c|}{ Fungsi } & \multicolumn{5}{|c|}{ Perangkat } \\
\hline & A & B & C & D & E \\
\hline 1 & $\begin{array}{l}\text { Menampilkan } \\
\text { informasi dari } \\
\text { menu Lokasi, } \\
\text { Wisata dan About }\end{array}$ & $\checkmark$ & $\checkmark$ & $\checkmark$ & $\checkmark$ & $\checkmark$ \\
\hline 2 & $\begin{array}{l}\text { Menampilkan } \\
\text { lokasi pengguna } \\
\text { pada peta }\end{array}$ & $\checkmark$ & $\checkmark$ & $\checkmark$ & $\checkmark$ & $\checkmark$ \\
\hline \multirow{2}{*}{3} & $\begin{array}{l}\text { Menampilkan } \\
\text { daftar Wisata } \\
\text { Alam, Wisata } \\
\text { Religi dan Wisata } \\
\text { Kuliner }\end{array}$ & $\checkmark$ & $\checkmark$ & $\checkmark$ & $\checkmark$ & $\checkmark$ \\
\hline 4 & $\begin{array}{l}\text { Menampilkan } \\
\text { informasi Wisata } \\
\text { Alam, Religi dan } \\
\text { Kuliner }\end{array}$ & $\checkmark$ & $\checkmark$ & $\checkmark$ & $\checkmark$ & $\checkmark$ \\
\hline 5 & $\begin{array}{l}\text { Menampilkan } \\
\text { Penanda dari lokasi } \\
\text { wisata yang di pilih }\end{array}$ & $\checkmark$ & $\checkmark$ & $\checkmark$ & $\checkmark$ & $\checkmark$ \\
\hline 6 & $\begin{array}{l}\text { Menampilkan rute } \\
\text { dari wisata yang di } \\
\text { pilih }\end{array}$ & $\checkmark$ & $\checkmark$ & $\checkmark$ & $\checkmark$ & $\checkmark$ \\
\hline
\end{tabular}


Keterangan :

$$
\begin{aligned}
& \sqrt{ }=\text { Berjalan } \\
& \mathrm{x}=\text { Tidak Berjalan }
\end{aligned}
$$

Keterangan :

1. Perangkat A:

1. Merk : Xiaomi Redmi 5A

2. Ram : $2 \mathrm{~GB}$

3. Ukuran Layar : 5.7 inches

4. Versi Android : Android 7.1.2 (Nougat)

2. Perangkat B:

1. Merk : Realme C2

2. Ram : $3 \mathrm{~GB}$

3. Ukuran Layar : 6.1 inches

4. Versi Android : Android $9.0(\mathrm{Pie})$

3. Perangkat $\mathrm{C}$ :
1. Merk : Oppo A5s
2. Ram : $3 \mathrm{~GB}$
3. Ukuran Layar
4. Versi Android : Android 8.1 (Oreo)

4. Perangkat $\mathrm{D}$

1. Merk : Oppo A3s

2. Ram : $2 \mathrm{~GB}$
3. Ukuran Layar : 6.2 inches

4. Versi Android : Android 8.1 (Oreo)

5. Perangkat E:

1. Merk : Xiaomi Redmi 6A

2. Ram : $3 \mathrm{~GB}$

3. Ukuran Layar : 5.45 inches

4. Versi Android : Android8.1 (Oreo)

\subsubsection{Pengujian Pengguna}

Untuk mengetahui respon pengguna terhadap aplikasi yang telah dibuat oleh penulis, maka penulis mengajukan 6 pertanyaan kepada 10 oranng responden. Pada pengujian kepuasan pengguna diambil hasil bahwa dari 10 reponden yang telah diberi kuisioner memberikan nilai kepuasan dari segi penggunaan, tampilan antarmuka, manfaat aplikasi dengan presentase sebanyak $0 \%$ menyatakan bahwa pengguna menytakan sangat kurang setuju, $0 \%$ pengguna menyatak kurang setuju, $15 \%$ menyatakan bahwa pengguna cukup setuju, 43,3\% menyatakan bahwa pengguna Setuju dan $41,6 \%$ menyatakan bahwa pengguna sangat setuju.

\begin{tabular}{|c|c|c|c|c|c|c|}
\hline \multirow{2}{*}{ No. } & \multirow{2}{*}{ Pernyataan } & \multicolumn{5}{|c|}{ Penilaian } \\
\hline & & SKS & KS & CS & $\mathbf{S}$ & SS \\
\hline 1. & Posisi pengguna yang ditampilkan dalam peta adalah akurat & - & - & 1 & 3 & 6 \\
\hline 2. & Aplikasi mudah di mengerti & - & - & 2 & 3 & 5 \\
\hline 3. & Proses untuk menentukan rute didalam peta cepat & - & - & 2 & 6 & 2 \\
\hline 4. & Semua menu berfungsi dengan baik & - & - & - & 6 & 4 \\
\hline 5. & Informasi wisata yang diberikan sudah lengkap & - & - & 4 & 4 & 2 \\
\hline 6. & Informasi ini bermanfaat bagi orang banyak & - & - & - & 4 & 6 \\
\hline & Persentase : & $0 \%$ & $0 \%$ & $15 \%$ & $43,3 \%$ & $41,6 \%$ \\
\hline
\end{tabular}

Tabel 4.2 Tabel hasil pengujian terhadap pengguna

Keterangan :

SKS : Sangat kurang Setuju

KS : Kurang Setuju

CS :Cukup Setuju

S :Setuju

SS : Sangat Setuju 


\section{KESIMPULAN DAN SARAN}

\subsection{Kesimpulan}

Berdasarkan hasil dari perancangan dan implementasi dari aplikasi pencarian tempat wisata menggunakan metode locaation based service pada kabupaten Timor Tengah Selatan berbasis android maka dapat diambil beberapa kesimpulan yaitu :

1. Aplikasi mampu mendapatkan posisi pengguna berdasarkan GPS.

2. Aplikasi dapat memberikan arah atau rute menuju wisata yang di pilih oleh pengguna.

\subsection{Saran}

Adapun saran sebagai acuan terhadap penilitian atau pengembangan selanjutnya, diantaranya :

1. Jumlah wisata bisah di tambahkan lagi.

2. Untuk Kedepanya aplikasi ini bisaditambahkan fitur untuk mengetahui pilihan rute alternatif.

\section{DAFTAR PUSTAKA}

[1] Budiman Edy, "PEMANFAATAN TEKNOLOGI LOCATION BASED SERVICE DALAM PENGEMBANGAN APLIKASI PROFIL KAMPUS UNIVERSITAS MULAWARMAN BERBASIS MOBILE", Jurnal Ilmiah ILKOM Vol. 8 No. 3, Desember 2016

[2] Anwar Badrul et al,'IMPLEMENTASI LOCATION BASED SERVICE BERBASIS ANDROID UNTUK MENGETAHUI POSISI
USER", Jurnal Ilmiah SAINTIKOM Vol. 13 No. 2, Mei 2014

[3] NTT Bangkit. 2016. "KABPATEN TIMOR TENGAH SELATAN". https://nttbangkit.wordpress.com/21-kabkota/kabupaten-timor-tengah-selatan/ (Diakses tanggal 24 Mei 2018)

[4] Qusay H. Mahmoud et al, "LOCATION BASED SERVICE". http://digilib.unila.ac.id/ 13229/12/ (Diakses tanggal 28 Juni 2018)

[5] Suyanto, Asep Herman, "PEMROGRAMAN JAVA : PENGENALAN JAVA”, www. Jurnalkomputer.com, 2015

[6] Raharjo, Budi, "BelajarOtodidak MySQL", 1 st ed., Bandung: Informatika Bandung, 2015

[7] Juansyah, Andi. 2015. "PEMBANGUNAN APLIKASI CHILD TRACKER BERBASIS ASSISTED - GLOBAL POSITIONING SYSTEM (A-GPS) DENGAN PLATFORM ANDROID ,'JurnalIlmiahKomputerdanInformati ka (KOMPUTA) Edisi 1 Volume. 1, Agustus 2015

[8] Anonymous, "Pengenalan JSON", http://www.json.org/json-id.html (diakses tanggal 24 Mei 2017)

[9] Mahdia, FayadanNoviyanto, Fiftin, "PEMANFAATAN GOOGLE MAPS API UNTUK PEMBANGUNAN SISTEM INFORMASI MANAJEMEN BANTUAN LOGISTIK PASCA BENCANA ALAM BERBASIS MOBILE WEB 